\title{
SOLIDARNOŚĆ W KONTEKŚCIE ZMIAN BAZOWEGO SYSTEMU EMERYTALNEGO W POLSCE W LATACH 1999-2011
}

\section{WPROWADZENIE}

Problematyka solidarności międzygeneracyjnej pojawiła się w dyskursie publicznym stosunkowo niedawno (M. Kohli podaje, że w 1984 r. w Stanach Zjednoczonych ${ }^{1}$ ). Praktyczne aspekty zagadnienia relacji międzypokoleniowych w polityce społecznej, przedstawiane często w kontekście „konfliktu pokoleń”, stały się przedmiotem dyskusji, ponieważ w wyniku istnienia systemu emerytalnego osoby starsze stały się głównymi ,klientami” państwa opiekuńczego, a także na skutek zmian demograficznych ${ }^{2}$. O sprawiedliwości międzygeneracyjnej mówi się głównie w kontekście warunku lub skutku długoterminowej (zarówno fiskalnej, jak i politycznej) wydolności systemu emerytalnego ${ }^{3}$. Wprowadzone reformy w zakresie (przede wszystkim) bazowego zabezpieczenia społecznego sa rozpatrywane głównie z punktu widzenia ich wpływu na redukcję wydatków publicznych (także w przyszłości). Z kolei skutki tych zmian w zakresie (re)dystrybucji pozostają w dużej mierze nieznane ${ }^{4}$.

Celem niniejszego artykułu jest rozważenie solidarności z punktu widzenia zmian systemu emerytalnego w Polsce, od paradygmatycznej reformy w $1999 \mathrm{r}$. do końca 2011 r. Rozważania ograniczają się do bazowego systemu emerytalnego ${ }^{5}$ i przeprowadzone zostały w kilku etapach. Pierwsza część dotyczy rozważań na temat solidarności w systemach emerytalnych w ogóle - rozumienia i interpretacji tego pojęcia, a także pomiaru zakresu solidarności w systemie emerytalnym. Druga część obejmuje rozważania dotyczące

\footnotetext{
${ }^{1}$ Szerzej na temat genezy M. Kohli, Generational Equity: Concepts and Attitudes, w: C. Arza, M. Kohli (red.), Pension Reform in Europe. Politics, Policies and Outcomes, Routledge/EUI Studies in the Political Economy of Welfare, London-New York 2008, s. 200 i n.

${ }^{2}$ Szerzej P. Szukalski, Co taczy pokolenia? Więz międzypokoleniowa z perspektywy polityki społecznej, „Polityka Społeczna” 2010, nr 10, s. 8; European Commission, Active Ageing and Solidarity between Generations. A Statistical Portrait of the European Union 2012, Luxembourg 2012.

${ }^{3}$ W. Schmähl, „Generationengerechtigkeit” als Begründung für eine Strategie ,nachhaltiger” Alterssicherung in Deutschland, w: idem, Soziale Sicherung. Ökonomische Analysen, VS Verlag für Sozialwissenschaften, Wiesbaden 2009, s. 401; M. Kohli, op. cit., s. 201.

${ }^{4}$ C. Arza, Changing European Welfare: The New Distributional Principles of Pension Policy, w: C. Arza, M. Kohli (red.), op. cit., s. 109.

${ }^{5}$ M. Żukowski, Wielostopniowe systemy zabezpieczenia emerytalnego $w$ Unii Europejskiej i $w$ Polsce. Między państwem a rynkiem, Zeszyty Naukowe - seria II, z. 151, Wydawnictwo Akademii Ekonomicznej w Poznaniu, Poznań 1997, s. 17 i n.
} 
(wybranych) zmian bazowego systemu emerytalnego w Polsce i konsekwencji tych zmian dla solidarności wewnątrz- i międzygeneracyjnej. Ostatnia część zawiera najważniejsze konkluzje.

\section{SOLIDARNOŚĆ W UBEZPIECZENIU EMERYTALNYM}

Pojęcie solidarności odnosi się do sytuacji współdziałania, wsparcia, wzajemnej odpowiedzialności, pomocy i troski między poszczególnymi członkami danej grupy, ,zgody na pewną ofiarę w imię jakiegoś wspólnego, powszechnie akceptowanego celu" ${ }^{6}$. Podkreśla się, że solidarność opiera się na wzajemności grupy wobec jednostki, ale także jednostki wobec grupy (często nazywana zasada ,,jeden za wszystkich, wszyscy za jednego"). H. Ribhegge zaznacza, że przy rozważaniu pojęcia solidarności należy odróżniać intencję, ideę (zamiar, zasadę) od faktycznego działania o charakterze solidarnościowym ${ }^{7}$. To ostatnie niekoniecznie musi wynikać z pobudek solidarnościowych ${ }^{8}$.

Na podstawie kryterium formalności lub jej braku wyróżnia się solidarność indywidualną i bezpośrednią (np. w rodzinie) lub zbiorową i pośrednią (np. w związku zawodowym) $)^{9}$. Ponadto można, w zależności od tego, gdzie ma miejsce solidarność, wyróżnić jej realizację w ujęciu grupowym (wewnątrz danej grupy) lub międzygrupowym (pomiędzy poszczególnymi grupami) ${ }^{10}$. Zazwyczaj przyjmuje się, że solidarność ma charakter dobrowolny. Bywa jednak, że solidarność jest wymuszana poprzez nakładanie obowiązku jej realizacji (i to w ujęciu wymuszonej solidarności grupowej i międzygrupowej).

W kontekście polityki społecznej, w tym zabezpieczenia społecznego, mówi się raczej o solidarności zbiorowej i pośredniej o charakterze zorganizowanym (którą dodatkowo określa się jako historyczną, narodową, międzygrupową), będącej zresztą odpowiedzia na niewystarczające tradycyjne formy wzajemnej pomocy ${ }^{11}$. ,W polityce społecznej zasada solidarności oznacza istnienie wzajemnych więzi wynikających z podobieństwa sytuacji życiowych i poglądów, które wzmocnione są poprzez poczucie wspólnoty i zbieżność interesów. Więzi te powinny być podstawą budowania solidarnych związków, przede wszystkim przez wspólnotę ubezpieczonych" ${ }^{12}$. Jako że ,solidarność jest dobrem rzadkim" ${ }^{13}$, polityka społeczna powinna nie tyle odwoływać się do moralnego poczucia (współ)odpowiedzialności i troski obywatela, ile być nakierowana na

${ }^{6} \mathrm{~S}$. Golinowska, O solidarności $i$ solidaryzmie $w$ polityce spotecznej, w: Polityka spoteczna: kontynuacja i zmiana. $Z$ okazji 90-lecia urodzin Profesora Antoniego Rajkiewicza naszego Honorowego Przewodniczacego Komitetu Nauk o Pracy i Polityce Spotecznej PAN, Instytut Pracy i Spraw Socjalnych, Warszawa 2012, s. 36 .

${ }^{7}$ H. Ribhegge, Sozialpolitik, Verlag Vahlen, München 2004, s. 43.

8 S. Golinowska, op. cit., s. 37.

${ }^{9}$ B. Rysz-Kowalczyk (red.), Leksykon polityki spotecznej, Instytut Polityki Społecznej Uniwersytetu Warszawskiego, Oficyna Wydawnicza ASPRA-JR, Warszawa 2002, s. 194.

${ }^{10}$ Ibidem, s. 195.

11 Ibidem, s. 196.

12 H. Lampert H., J. Althammer, Lehrbuch der Sozialpolitik, wyd. 6 zmienione, Springer-Verlag, Berlin-Heidelberg-New York 2001, s. 422 (tłum. własne).

${ }^{13}$ H. Ribhegge, op. cit., s. 43. 
stworzenie instytucji, które motywuja jednostki do zachowań solidarnościowych ze względu na indywidualne korzyści wynikające z takiej postawy - chodzi tu głównie o element indywidualnej przezorności ${ }^{14}$.

$\mathrm{W}$ rozważaniach dotyczących solidarności w zabezpieczeniu społecznym M. Rymsza wyróżnia: solidarność poziomą (horyzontalną) i solidarność pionową (wertykalną). Solidarność pozioma utożsamiana jest z (technicznym) wyrównaniem ryzyka ubezpieczeniowego $\mathrm{w}$ grupie ubezpieczonych podmiotów ${ }^{15}$. Zaznaczyć należy, że w literaturze ubezpieczeniowej określenie to stosuje się w odniesieniu do ryzyka rozumianego jako indywidualny rozkład prawdopodobieństwa odchyleń wartości faktycznej od oczekiwanej ${ }^{16}$.

Solidarność pionowa wiąże się z redystrybucją między ubezpieczonymi (a więc wewnątrz grupy podmiotów objętych ochroną) lub redystrybucją obejmującą także podmioty, które nie należą do wspólnoty ubezpieczonych ${ }^{17}$. Oba te aspekty są szczególnie ważne w kontekście ubezpieczeń społecznych, gdyż faza aktywności ma bezpośredni wpływ na wysokość świadczeń w fazie starości. Solidarność pionową odnosi się najczęściej do braku lub naruszenia indywidualnej ekwiwalentności świadczenia ${ }^{18}$. Jest ona ściśle związana z przyjętą „miara/sposobem” wartościowania wniesionego wkładu. W odniesieniu do tej zależności istotne jest określenie:

1) co należy rozumieć przez pojęcie wkładu do systemu;

2) jak wkład ten (lub poszczególne jego składowe) należy „,przeliczyć” na świadczenie emerytalne.

Wkład do systemu rozumiany jest przede wszystkim jako wniesione składki (od dochodu z pracy zarobkowej). Pojęcie wkładu rozszerzone może być jednak o dodatkowe czynności, które uznaje się za równoważne z odprowadzaniem składek. Długość okresu wkładu do systemu odgrywa w systemach ubezpieczeniowych zazwyczaj podwójną rolę: stanowi kryterium otrzymania świadczenia

14 S. Golinowska, op. cit., s. 39.

${ }_{15}$ M. Rymsza, Solidaryzm w ubezpieczeniach społecznych, w: T. Szumlicz (red.), Spoteczne aspekty ubezpieczenia, Szkoła Główna Handlowa w Warszawie, Warszawa 2005, s. 43.

${ }^{16}$ Szerzej na temat tak ujętego ryzyka np. D. Farny, Versicherungsbetriebslehre, wyd. 2 zmienione, VVW, Karlsruhe 1995, s. 17 i n. Samo ,wyrównanie ryzyka” ma znaczenie przede wszystkim dla podmiotu ,organizującego” ubezpieczenie (oznacza wyrównywanie, całkowite lub częściowe, poszczególnych indywidualnych różnic, dodatnich lub ujemnych, między rzeczywistą a oczekiwaną wartością szkód); pojedynczy nabywca ochrony ubezpieczeniowej kupuje jedynie pewność wypłaty świadczenia według wcześniej ustalonych reguł.

${ }^{17}$ Tę ostatnią, o ile dotyczy wspólnoty państwowej (np. w odniesieniu do pomocy społecznej), M. Rymsza określa mianem solidarności obywatelskiej (op. cit., s. 43). Autor wiąże ją głównie z doktryną państwa opiekuńczego, w którym działania nakierowane są na zapewnienie ochrony socjalnej wszystkim obywatelom wraz z postulatem wyrównywania poziomu życia (op. cit., s. 47).

${ }^{18}$ Tak np. B. Rysz-Kowalczyk, op. cit., s. 196-197. Indywidualna ekwiwalentność świadczenia to ekwiwalentny matematycznie związek między indywidualnym wkładem (jego nominalną wartością) a wysokością indywidualnego świadczenia. Ekwiwalentność świadczenia można także ujmować globalnie. T. Szumlicz indywidualną ekwiwalentność (matematyczną) świadczenia nazywa ekwiwalentnością ,„świadczeniowa” (T. Szumlicz, Zabezpieczenie emerytalne w systemach zabezpieczenia spotecznego, w: idem, M. Żukowski (red.), Systemy emerytalne w krajach Unii Europejskiej, Twigger, Warszawa 2004, s. 22, przyp. 20) lub „,kompensacyjną” (T. Szumlicz, Ubezpieczenie spoteczne. Teoria dla praktyki, Oficyna Wydawnicza Branta, Bydgoszcz-Warszawa 2005, s. 94), natomiast globalną ekwiwalnentość (matematyczną) świadczeń - ekwiwalentnością „funduszową” (T. Szumlicz, Zabezpieczenie..., s. 22, przyp. 20; idem, Ubezpieczenie..., s. 94). 
w ogóle (okres wyczekiwania jako minimalny okres przynależności do wspólnoty ubezpieczonych) i jest determinantą wysokości świadczenia.

Wartościowanie poszczególnych rodzajów wkładów może przybierać różne formy:

1) w odniesieniu do odprowadzonych składek:

a) - bezpośredniego przeliczenia wpłaconych (lub naliczonych, lub należnych) składek na wysokość emerytury,

b) - pośredniego przeliczania wpłaconych (lub naliczonych, lub należnych) składek na wysokość świadczenia (np. opartego na podstawie wymiaru składek);

2) w odniesieniu do określonych czynności z fazy aktywności:

a) - poprzez przypisanie im wartości określonej wysokości składki (w ujęciu np. miesięcznym) ${ }^{19}$; wówczas przeliczanie wpływu tych czynności odbywa się tak samo jak w wypadku wnoszenia wkładu $\mathrm{w}$ formie składek (a więc w sposób pośredni lub bezpośredni);

b) - poprzez „wycenienie” w konkretnej wysokości i stosowanie dopłat do emerytury.

W wypadku bezpośredniego przeliczania wkładu (w formie składek lub określonych, honorowanych czynności) formuła emerytalna przybiera postać formuły ze zdefiniowaną składka, co oznacza, że jej wysokość bezpośrednio zależy od zgromadzonego (fikcyjnego lub rzeczywistego, w zależności od metody finansowania) indywidualnego kapitału ${ }^{20}$. W wypadku pośredniego przeliczania wkładu do systemu lub stosowania kwotowej wyceny wkładu formuła emerytalna przybiera postać formuły ze zdefiniowanym świadczeniem (tj. takim, które przy standardowym przebiegu kariery zawodowej powinno zagwarantować pożądaną politycznie wysokość emerytury ${ }^{21}$ ).

Jak wspomniano wyżej, solidarność pionową odnosi się najczęściej do braku lub naruszenia indywidualnej ekwiwalentności świadczenia ${ }^{22}$. Należy jednak podkreślić, że solidarność pionowa może być także realizowana poprzez brak lub naruszenie indywidualnej ekwiwalentności składki ${ }^{23}$ (o ile świadczenia będą

${ }^{19}$ Składka ta może być albo ,fikcyjnie” przypisywana jako wkład danego podmiotu (i ostatecznie, tj. przy wypłacie świadczeń, finansowana dodatkowo przez pozostałych ubezpieczonych lub/i państwo w wysokości różnicy pomiędzy ,składkową” i należną emerytura), albo faktycznie odprowadzana przez podmioty trzecie równocześnie $\mathrm{z}$ wykonywaniem owej honorowanej czynności.

${ }^{20}$ Zaznaczyć należy, że ta formuła nawet w sposób pośredni nie nawiązuje do pokrycia zapotrzebowania (indywidualnego, przeciętnego) w fazie starości.

${ }^{21}$ Co w większym stopniu może zapewnić pokrycie (przeciętnego, indywidualnego) zapotrzebowania na środki pieniężne w okresie zaprzestania aktywności zawodowej.

${ }^{22} \mathrm{~Np}$. J. Rutecka stoi na stanowisku, że techniczne wyrównanie ryzyka nie jest redystrybucją, ale przejawem solidarności społecznej (utożsamianej z wzajemnością ubezpieczeniową); autorka nie ujmuje braku ekwiwalentności składki jako element determinujący redystrybucję w systemie emerytalnym, ograniczając ją wyłącznie do braku (indywidualnej) ekwiwalentności świadczenia (J. Rutecka, Zakres redystrybucji dochodowej $w$ ubezpieczeniowym systemie emerytalnym, Oficyna Wydawnicza Szkoła Główna Handlowa w Warszawie, Warszawa 2012, s. 111, 113 i 224).

${ }^{23}$ A więc związku między indywidualnym prawdopodobieństwem zajścia zdarzenia wywołującego prawo do świadczeń a indywidualną stopą składki. Wyróżnić można także globalną ekwiwalentność składki, która odnosić się będzie do całej grupy osób objętych ubezpieczeniem (w fazie gwarancyjnej, tj. gromadzenia uprawnień emerytalnych). Ekwiwalentność składki może być także rozumiana z perspektywy subiektywnej, tj. indywidualnego i subiektywnego (poczucia) równoważności wartości otrzymanej ochrony ubezpieczeniowej (zakupionej pewności) i (wartości) nakładu pieniężnego (ceny) za ową 
finansowane $\mathrm{z}$ tego źródła, tj. metodą ubezpieczeniową ${ }^{24}$ ). W literaturze często wszelkie elementy naruszające (indywidualną) ekwiwalentność składki lub świadczenia określane są mianem elementów solidarnościowych, elementów wyrównania socjalnego lub elementów pozaubezpieczniowych.

Istnienie obu typów solidarności w ubezpieczeniu (emerytalnym) nie wiąże się z koniecznością narzucenia obowiązku tworzenia lub przynależności do wspólnot ubezpieczeniowych. Pierwotnie bowiem takie wspólnoty opierały się na na dobrowolnej solidarności wewnątrzgrupowej i to ona była podstawa budowania więzi instytucjonalnych ${ }^{25}$. Wymuszenie solidarności poprzez narzucenie obligatoryjności $\mathrm{w}$ ubezpieczeniu emerytalnym może być uzasadniane istnieniem negatywnych efektów zewnętrznych ${ }^{26}$. Obligatoryjność ma wówczas charakter instrumentalny. Służy osiaggnięciu takich celów, jak zapewnienie zabezpieczenia na starość każdemu obywatelowi, ale także daje możliwość lepszego „,technicznego rozłożenia ryzyka ubezpieczeniowego" ${ }^{27} \mathrm{i}$ zastosowania rachunku aktuarialnego do ,,produkcji” ubezpieczenia. Sam fakt obligatoryjności nie musi jednak generować istnienia solidarności pionowej (choć z pewnością wiąże się $\mathrm{z}$ obecnością solidarności poziomej ${ }^{28}$ ). Występowanie elementów solidarności pionowej ma związek z realizacja sprawiedliwości (głównie pionowej).

Rozważanie solidarności w (bazowym) zabezpieczeniu emerytalnym odnosi się do dystrybucji i redystrybucji dochodu, dokonywanych w ramach systemu bazowego. Podział dochodu w odniesieniu do (bazowego) systemu emerytalnego określany jest w odniesieniu do trzech następujących (pod)obszarów ${ }^{29}$ :

pewność. Stąd ekwiwalentność tę określa się czasem mianem „ekwiwalentności pewności” (N. Barr, Ekonomika polityki społecznej, tłum. M. Żukowski, Wydawnictwo Akademii Ekonomicznej w Poznaniu, Poznań 1993, s. 129 i n.). Ma to znaczenie głównie w ubezpieczeniach dobrowolnych, w których stanowi istotną przesłankę prowadzonej polityki cenowej (,,ta sama pewność” sprzedawana jest po różnej cenie G. Wagner, Umverteilung in der gesetzlichen Rentenversicherung, Campus Verlag, Frankfurt-New York 1984, s. 9 i n.). Ze względu na obligatoryjność przedmiotu analizy niniejszego artykułu, tj. bazowego zabezpieczenia emerytalnego, podejście takie nie będzie uwzględniane.

${ }^{24}$ Tak np. H. Ribhegge, op. cit., s. 42.

${ }^{25}$ Szerzej M. Rymsza, op. cit., s. 46 i n. Odrębną kwestią jest to, w jakim stopniu instytucjonalizacja wzajemności przyczyniła się do atrofii więzi społecznych (M. Rymsza, op. cit., s. 45 i n.; odmiennie P. Szukalski, op. cit., s. 10).

${ }^{26}$ Szerzej np. M. Góra, System emerytalny, Polskie Wydawnictwo Ekonomiczne, Warszawa 2003, s. $23 \mathrm{i} \mathrm{n.}$

${ }^{27} \mathrm{~W}$ tym kontekście należy nadmienić, że spornym jest, jak należy rozumieć ryzyko emerytalne. Pojawiają się argumenty, że ustalanie minimalnego wieku emerytalnego decyzją polityczną (bazując raczej na przesłance wysługi, a nie biologicznej) jest przesłanką uznania starości za zdarzenie zrównane z ryzykiem socjalnym (M. Rymsza, op. cit., s. 53). Z drugiej strony jednak mamy do czynienia z losowością rozumianą jako dożycie lub nie określonego wieku. Wiek ten praktycznie nigdy nie wiązał się z niezdolnością do pracy na tle starości. Podobnie jest w ubezpieczeniach gospodarczych. Przytaczany z kolei argument dotyczący tego, że w razie śmierci w okresie akumulacji uprawnień emerytalnych wypłacane jest świadczenie rentowe (renta wdowia lub rodzinna) jest chybione, to świadczenie bowiem jest zakresem przedmiotowym ubezpieczenia rentowego, nie emerytalnego.

${ }^{28}$ Inne stanowisko prezentuje M. Góra: „Żaden obowiązkowy system nie jest - bo nie może być solidarnościowy. Z solidarnością mamy do czynienia wtedy, gdy ktoś z własnej woli dzieli się z innym, który tego potrzebuje” (op. cit., s. 42). Jednocześnie jednak autor stwierdza, że „W sferze realnej natomiast oba systemy - zarówno repartycyjny, jak i kapitałowy - są solidarnościowe (op. cit., s. 43).

${ }^{29} \mathrm{~W}$. Schmähl, Zielvorstellungen in der Diskussion über die Alterssicherung - Eine Skizze, „Zeitschrift für Gerontologie” 13, 1980, z. 3, s. 233 i n. 
- utrzymanie relatywnej pozycji dochodowej;

- unikanie ubóstwa - gwarancja minimalnego dochodu;

- zmniejszanie nierówności dochodowych.

Na miarę normatywnej oceny i wagi realizacji powyższych celów (oraz ich zmiany) tworzona (a obecnie raczej dostosowywana) powinna być konstrukcja bazowego zabezpieczenia emerytalnego.

Każdy z wymienionych trzech celów można rozważać przez pryzmat następujących aspektów podziału dochodu:

- podział dochodu konkretnej jednostki w cyklu życia,

- podział dochodu w ramach danej generacji,

- podział dochodu pomiędzy generacjami.

Operacjonalizacja $\mathrm{w}$ ramach każdego $\mathrm{z}$ wyżej wymienionych aspektów podziału dochodu wymaga wyboru kryterium oceny stopnia realizacji celu, a także określenia, w jaki sposób ustalony zostanie wskaźnik oparty na tym kryterium. Ostatni poziom celów obejmuje sprecyzowanie pożądanego poziomu wcześniej wyznaczonego wskaźnika stopnia realizacji celu cząstkowego (tabela 1).

Istotne w kontekście rozważań o solidarności jest dookreślenie pojęcia „generacja”. W niniejszym opracowaniu przyjęto, że jest to ogół jednostek kohorty (kohort) finansującej świadczenia ( $\mathrm{w}$ wieku produkcyjnym lub faktycznie zarobkujących) lub kohorty (kohort) beneficjentów świadczeń ${ }^{30}$. W tym sensie ,starość systemowa” wyznaczana jest poprzez zinstytucjonalizowany minimalny wiek emerytalny; jego zmiana prowadzi do rozszerzenia lub zawężenia generacji i tym samym wpływa na redystrybucję dochodu (i innych dóbr) między beneficjentów emerytur i finansujących te świadczenia $^{31}$.

Podział dochodu jednostki ${ }^{32} \mathrm{w}$ cyklu życia (tj. podziału w dwóch jego fazach: aktywności i starości) zmierzyć można za pomoca indywidualnej stopy zastąpienia (tj. relacja otrzymywanej emerytury do wcześniejszych dochodów) ${ }^{33}$. Istotne w tym ujęciu jest doprecyzowanie pojęć „emerytura” (bazowa,

${ }^{30} \mathrm{Na}$ temat innych ujęć: P. Szukalski, op. cit., s. 7; B. Szatur-Jaworska, Solidarność międzypokoleniowa $w$ polityce społecznej, w: Polityka spoteczna: kontynuacja i zmiana..., s. 81. P. Szukalski rozróżnia przy tym cztery pojęcia odnoszące się do układów międzypokoleniowych (op. cit., s. 8 i 9): relacje międzypokoleniowe (,„ktoś z innego pokolenia jest obok nas”), więzi międzypokoleniowe (powinniśmy coś dla innych pokoleń zrobić, a przynajmniej się z ich interesem liczyć”), solidarność międzypokoleniowa (,„musimy coś dla nich zrobić”) i kontrakt międzypokoleniowy (,,zróbmy to i to”). Z tym ostatnim wiąże się pojęcie sprawiedliwości międzypokoleniowej (i konfliktu międzypokoleniowego), a ta z kolei wiąże się $\mathrm{z}$ akceptowanym społecznie podziałem wyznaczników statusu. W odniesieniu do zabezpieczenia emerytalnego (zwłaszcza bazowego) można mówić o publicznym kontrakcie międzypokoleniowym (szerzej ibidem, s. 9), i to rozumianym raczej jako typowa redystrybucja posiadanych zasobów.

${ }^{31}$ Tak np. M. Kohli, op. cit., s. 197. Jest to istotne w kontekście dyskusji i propozycji dotyczącej wyrównania i podwyższenia wieku emerytalnego kobiet i mężczyzn w Polsce.

${ }^{32}$ Chodzi o indywidualny dochód i-tej jednostki w ujęciu wieloletnim.

${ }^{33}$ T. Szumlicz stosuje nazwę ,,indywidualny wskaźnik zastąpienia” (który definiuje jako stosunek ostatniego indywidualnego dochodu do pierwszej emerytury), w odróżnieniu od ogólnego wskaźnika zastąpienia (który stanowi iloraz przeciętnej wielkości emerytury do średnich zarobków wszystkich beneficjentów -idem, Ubezpieczenie..., s. 248). J. Jończyk używa z kolei terminów „,stopa świadczenia” lub „,stopa kompensacji” (J. Jończyk, Prawo zabezpieczenia społecznego, Zakamycze, Kraków 2006, s. 146). 
netto czy brutto) i „,dochód” (finansowy, z pracy zarobkowej czy ogólny; brutto czy netto; nominalny czy realny), a także jednoznaczne wskazania sposobu pomiaru ( $\mathrm{w}$ tym uwzględnianego zakresu czasowego). Nadto można także stosować wskaźnik wartości bieżącej przepływów emerytalnych netto, stopy składkowania netto, współczynnika wartości bieżącej czy wewnętrznej stopy zwrotu $^{34}$. Biorąc pod uwagę wcześniej wymienione cele (bazowego) systemu emerytalnego, można wskazać przykładowe instrumenty służące ich realizacji. I tak utrzymaniu dotychczasowego poziomu życia może służyć na przykład związanie wysokości emerytury z poprzednio uzyskiwanym dochodem; unikaniu ubóstwa - emerytura minimalna, zmniejszeniu nierówności dochodowych - na przykład ustalanie takich warunków przyznawania świadczenia, by mogły one być spełnione przez większość potencjalnych beneficjentów ${ }^{35}$.

Podział dochodu $\mathrm{w}$ ramach danej generacji może być analizowany $\mathrm{w}$ odniesieniu do kohorty (kohort) finansującej świadczenia lub do kohorty (kohort) beneficjentów świadczeń. W pierwszym wypadku analiza dotyczy przede wszystkim źródeł dochodów, w drugim - struktury emerytur. Kryterium oceny może być konstrukcja podstawy i skali naliczania należności (grupa podmiotów finansujących świadczenia) lub poziom i metoda wyznaczania wysokości emerytury (grupa beneficjentów). W zależności od potrzeb informacyjnych moga być w tym zakresie definiowane różne wskaźniki, na przykład wskaźnik (relatywnego) zróżnicowania wysokości emerytur ${ }^{36}$, wskaźnik efektywnej progresywności ${ }^{37}$ czy indeks progresywności ${ }^{38}$. Pierwszy i trzeci wymieniony wskaźnik pozwala jednak jedynie na stwierdzenie faktu istnienia redystrybucji, natomiast nie pozwala na dokładną ocenę kierunków redystrybucji i grup beneficjentów ${ }^{39}$. Instrumentami, które mogą służyć realizacji celu utrzymania dotychczasowego poziomu życia $\mathrm{w}$ odniesieniu do generacji finansującej świadczenia, może być przykładowo ustalenie obciążeń w powiązaniu z otrzymywanym dochodem, a w przypadku generacji beneficjentów - „neutralność” systemu, czyli jednolite dla wszystkich zasady wyznaczania wysokości emerytur. Z kolei cel unikania ubóstwa w odniesieniu do generacji finansujaccej świadczenia może być realizowany poprzez ustalenie dolnej granicy dochodów,

\footnotetext{
${ }^{34}$ Szerzej J. Rutecka, op. cit., s. 146 i n.

${ }^{35}$ Oczywiście w ubezpieczeniu emerytalnym mamy także do czynienia z redystrybucją dochodu w czasie w kontekście jednostki. M. Rymsza twierdzi (op. cit., s. 49), że „redystrybucja pozioma” i „,redystrybucja w czasie” [rozumiana jako gromadzenie środków finansowych przed zajściem zdarzeń objętych ubezpieczeniem - J.R.T.] są ... dwoma aspektami tego samego transferu środków finansowych". Ze stanowiskiem takim można polemizować, bowiem możliwa jest np. redystrybucja w czasie (w postaci samoubezpieczenia), bez redystrybucji poziomej (rozumianej jako techniczne wyrównywanie ryzyka w grupie ubezpieczonych). Analogicznie w ubezpieczeniach krótkoterminowych (choć do takich nie należą ubezpieczenia emerytalne) redystrybucja w czasie jest bardzo ograniczona (może też w ogóle nie występować), natomiast redystrybucja pionowa mam miejsce (bo jest ona elementem ,,produkcji” ochrony ubezpieczeniowej).

${ }^{36}$ Szerzej J. Rutecka, op. cit., s. 136 i n. Nadto, jego obliczenie (w zmodyfikowanej formie) będzie trudne przy zmiennej dla danej kohorty stopie składki emerytalnej lub limitów podstawy wymiaru składek.

${ }^{37}$ Wskaźnik ten odnosi się do kohorty finansującej świadczenia emerytalne poprzez opłacanie składek. Szerzej J. Rutecka, op. cit., s. 141-142.

${ }^{38}$ Ibidem, s. 143 i n.

${ }^{39}$ Ibidem, s. 138 i 146.
} 
poniżej której istnieje zwolnienie $\mathrm{z}$ obowiązku finansowania świadczeń emerytalnych; w odniesieniu do generacji emerytów może to być zagwarantowanie wszystkim emerytom minimalnej emerytury. Cel zmniejszania nierówności dochodowych może być realizowany za pomocą takich instrumentów, jak ustalenie dolnego i górnego progu dochodu zwalniającego od obowiązku finansowania świadczeń dla generacji finansującej emerytury; określenie górnej lub dolnej granicy poziomu emerytury dla generacji beneficjentów.

Analiza podziału dochodu pomiędzy generacje wymaga między innymi określenia, jakiego okresu (którego momentu czasowego) i jakich wielkości (fikcyjnych czy rzeczywistych; realnych czy nominalnych, brutto czy netto) pomiar ma dotyczyć. Przedmiotem pomiaru mogą być ${ }^{40}$ : przy analizie na dany moment - bezwzględna wartość środków (dla obu wyróżnionych grup) lub względna wartość tych środków; w odniesieniu do analizy długoterminowej - globalna ekwiwalentność matematyczna świadczeń danej kohorty lub kohort ${ }^{41}$. Analizując solidarność międzygeneracyjną, rozważa się zazwyczaj wartości względne, ograniczając analizę do bieżącego podziału PKB między generacje pracującą i generację emerytów (M. Góra tak nawet definiuje cel systemu emerytalnego ${ }^{42}$ ). Jednym ze stosowanych mierników może być porównanie wysokości średniej emerytury do średnich zarobków, a więc określenie systemowej przeciętnej stopy zastapienia z systemu bazowego (ex ante lub ex post) lub tak zwanej relacji stóp zysku (wewnętrznych stóp zwrotu dla poszczególnych kohort z systemu emerytalnego ${ }^{43}$. Instrumentami, które moga służyć realizacji celu utrzymania dotychczasowej pozycji dochodowej, a także unikaniu ubóstwa, mogą być waloryzacja kapitału emerytalnego lub emerytur i modyfikacja formuły emerytalnej. Z kolei cel zmniejszania nierówności dochodowych może być osiagany poprzez opodatkowanie emerytur (oraz wyżej wymienione instrumenty).

Solidarność pozioma ma miejsce przede wszystkim w ramach danej generacji. Można jednak wskazywać także przykłady jej istnienia pomiędzy generacjami ${ }^{44}$.

Solidarność pionowa może mieć miejsce zarówno w ramach danej generacji, jak i pomiędzy generacjami finansującymi emerytury i beneficjentami. Teoretycznie można sobie wyobrazić sytuację, gdy nie ma indywidualnej ekwiwalentności składki, ale jest zachowana ona w ujęciu globalnym. Oznaczałoby to wówczas, iż (wymuszona) solidarność ogranicza się wyłącznie do grupy ubezpieczonych, to znaczy że wewnątrz tej grupy następuje (techniczne) wyrównanie ryzyka. Najczęściej jednak tak nie jest, stopa składki emerytalnej

${ }^{40} \mathrm{~Np}$. W. Schmähl, ,Generationengerechtigkeit”..., s. 402.

${ }^{41}$ Tym samym można porównać wartości wskaźników odnoszących się do rozkładu dochodu jednostki w ciągu życia obliczone dla kohort (lub podgrup w ramach kohort). Tak np. N. Barr, P. Diamond, Pension Reform. A Short Guide, Oxford University Press, Oxford 2010, s. 31. Nie można zapomnieć o tym, że generacje pobierające świadczenia emerytalne także są podatnikami i w sposób pośredni (o ile istnieje dotacja do systemu bazowego) finansują świadczenia.

${ }^{42}$ M. Góra, op. cit., s. 13.

${ }^{43}$ C. Arza, op. cit., s. 122; W. Schmähl, „Generationengerechtigkeit”..., s. 404 i n.

${ }^{44} \mathrm{Na}$ ten temat np. G. Wagner, Zur Messbarkeit eines versicherungsgemäeßn Risikoausgleichs und der Umverteilung in der gesetzlichen Rentenversicherung, w: W. Schmähl (red.), Versicherungsprinzip und soziale Sicherung, J. C. B. Mohr (Paul Siebeck), Tübingen 1985, s. 145 i n. 
Tabela 1

Cele cząstkowe (bazowego) zabezpieczenia emerytalnego w odniesieniu do różnych aspektów podziału dochodów

\begin{tabular}{|c|c|c|c|c|}
\hline \multirow{2}{*}{$\begin{array}{l}\begin{array}{r}\text { Aspekty } \\
\text { analizy }\end{array} \\
\\
\\
\text { Cele } \\
\text { cząstkowe }\end{array}$} & \multirow{2}{*}{$\begin{array}{c}\text { Podział } \\
\text { dochodu } \\
\text { jednostki } \\
\text { w cyklu } \\
\text { życia }\end{array}$} & \multicolumn{2}{|c|}{$\begin{array}{c}\text { Podział dochodu w ramach } \\
\text { danej generacji }\end{array}$} & \multirow{2}{*}{$\begin{array}{c}\text { Podział } \\
\text { dochodu } \\
\text { pomiędzy } \\
\text { generację } \\
\text { finansujaca } \\
\text { świadczenia } \\
\text { i beneficjentów }\end{array}$} \\
\hline & & $\begin{array}{c}\text { Generacja } \\
\text { finansujaca } \\
\text { emerytury }\end{array}$ & $\begin{array}{l}\text { Generacja } \\
\text { świadczenio- } \\
\text { biorców }\end{array}$ & \\
\hline $\begin{array}{l}\text { Przykładowe } \\
\text { kryterium oceny } \\
\text { stopnia realizacji } \\
\text { celu cząstkowego }\end{array}$ & $\begin{array}{l}\text { Indywidualny } \\
\text { poziom } \\
\text { emerytury } \\
\text { bazowej }\end{array}$ & $\begin{array}{l}\text { Podstawa } \\
\text { i skala składek } \\
\text { na emerytury }\end{array}$ & $\begin{array}{l}\text { Struktura } \\
\text { (poziom i metoda } \\
\text { obliczania) } \\
\text { wypłacanych } \\
\text { emerytur }\end{array}$ & $\begin{array}{l}\text { Poziom } \\
\text { (przeciętnej) } \\
\text { emerytury } \\
\text { w stosunku do } \\
\text { (przeciętnej) } \\
\text { płacy; stopa } \\
\text { zysku z systemu } \\
\text { emerytalnego }\end{array}$ \\
\hline $\begin{array}{l}\text { Utrzymanie } \\
\text { relatywnej } \\
\text { pozycji } \\
\text { dochodowej } \\
\text { z okresu } \\
\text { aktywności }\end{array}$ & $\begin{array}{l}\text { Utrzymanie } \\
\text { dotychczasowego } \\
\text { poziomu życia } \\
\text { danego } \\
\text { beneficjenta; }\end{array}$ & $\begin{array}{l}\text { Utrzymanie } \\
\text { relatywnej } \\
\text { pozycji } \\
\text { dochodowej } \\
\text { względem } \\
\text { pozostałych } \\
\text { członków } \\
\text { kohorty }\end{array}$ & $\begin{array}{l}\text { Utrzymanie } \\
\text { relatywnej } \\
\text { pozycji } \\
\text { dochodowej } \\
\text { względem } \\
\text { pozostałych } \\
\text { członków } \\
\text { kohorty }\end{array}$ & $\begin{array}{l}\text { Utrzymanie } \\
\text { odpowiedniego } \\
\text { stosunku } \\
\text { pomiędzy } \\
\text { wysokościa } \\
\text { dochodu } \\
\text { obu grup }\end{array}$ \\
\hline $\begin{array}{l}\text { Unikanie } \\
\text { ubóstwa }\end{array}$ & $\begin{array}{l}\text { Zagwarantowanie } \\
\text { minimalnego } \\
\text { świadczenia } \\
\text { danemu } \\
\text { beneficjentowi }\end{array}$ & $\begin{array}{l}\text { Niwelacja (lub } \\
\text { ograniczenie) } \\
\text { obciążenia na } \\
\text { rzecz świadczeń } \\
\text { w przypadku, } \\
\text { gdy wiązałoby } \\
\text { się to z obniże- } \\
\text { niem dochodu } \\
\text { poniżej przyję- } \\
\text { tego poziomu } \\
\text { minimalnego }\end{array}$ & $\begin{array}{l}\text { Zagwarantowanie } \\
\text { minimalnego } \\
\text { dochodu } \\
\text { każdemu } \\
\text { beneficjentowi } \\
\text { emerytury }\end{array}$ & $\begin{array}{l}\text { Zapobieganie } \\
\text { obniżeniu } \\
\text { dochodu } \\
\text { emerytalnego } \\
\text { poniżej } \\
\text { określonego } \\
\text { poziomu }\end{array}$ \\
\hline $\begin{array}{l}\text { Zmniejszanie } \\
\text { nierówności } \\
\text { dochodowych }\end{array}$ & $\begin{array}{l}\text { Niwelowanie } \\
\text { (lub minimalizo- } \\
\text { wanie) wpływu } \\
\text { czynników } \\
\text { determinujących } \\
\text { prawo } \\
\text { do świadczeń } \\
\text { i ich wysokość } \\
\text { w razie ich } \\
\text { negatywnego } \\
\text { przebiegu }\end{array}$ & $\begin{array}{l}\text { Ograniczenia } \\
\text { w finansowaniu } \\
\text { świadczeń } \\
\text { w razie zbyt } \\
\text { wysokiego lub } \\
\text { zbyt niskiego } \\
\text { dochodu }\end{array}$ & $\begin{array}{l}\text { „Wybiórcze” } \\
\text { korygowanie } \\
\text { wysokości } \\
\text { emerytur } \\
\text { w wypadku ich } \\
\text { zbyt wysokiego } \\
\text { lub niskiego } \\
\text { poziomu }\end{array}$ & $\begin{array}{l}\text { „Generalne” } \\
\text { korygowanie } \\
\text { wysokości } \\
\text { emerytur } \\
\text { w wypadku ich } \\
\text { zbyt wysokiego } \\
\text { lub niskiego } \\
\text { poziomu }\end{array}$ \\
\hline
\end{tabular}

Źródło: opracowanie własne na podstawie W. Schmähl, Soziale Sicherung im Alter, w: Handwrterbuch der Wirtschaftswissenschaft, t. 6, Fischer/Mohr, Stuttgart i in. 1988, s. 643 i n. 
w ubezpieczeniu obowiązkowym nie spełnia bowiem kryteriów ekwiwalentności globalnej - nie odpowiada faktycznemu uśrednionemu ryzyku w grupie ubezpieczonych, ale jest ustalana według innych kryteriów (np. politycznych). Analogicznie często mamy do czynienia $\mathrm{z}$ brakiem globalnej ekwiwalentności świadczenia, który jest pochodną braku owej ekwiwalentności w ujęciu indywidualnym. W takiej sytuacji, zwłaszcza gdy ma miejsce dopłata budżetowa (lub z innych zewnętrznych źródeł) do funduszu ubezpieczeniowego, można mówić o rozszerzeniu obligatoryjnej solidarności o grono współfinansujących dopłatę (np. podatników, którzy nie są objęci ubezpieczeniem emerytalnym, a którzy mogą nie być świadomi, że w sposób wymuszony realizują zachowania solidarnościowe).

Kwestią normatywną jest, jaki zakres ma solidarność (głównie) pionowa wewnątrz- i międzygeneracyjna ${ }^{45}$, w szczególności, jaka część PKB powinna przypadać emerytom oraz czy ma to być część stała PKB dla pokolenia emerytów, czy też stała w ujęciu indywidualnego beneficjenta ${ }^{46}$.

Decyzja, co do tego, jaka część PKB ma przypadać generacji emerytów, ma jak wyżej wspomniano - charakter normatywny $\mathrm{i}$ jest przedmiotem endolub egzogenicznego wyboru publicznego ${ }^{47}$. Jeśli przyjmuje się, że ,dobrobyt wszystkich pokoleń jest równie ważny, to istnieje tylko jedna równowaga Arrowa-Debreu (tzn. równowaga Nasha w »grze międzypokoleniowej«), która jest optymalna także w sensie Pareta. Wymaga ona, aby każde pokolenie uczestniczące $\mathrm{w}$ systemie otrzymywało $\mathrm{z}$ niego tyle samo, ile do niego wpłaciło (po skorygowaniu o stopę wzrostu produktu)" ${ }^{48}$. W tym sensie można mówić o konieczności zachowania ekwiwalentności świadczenia o charakterze globalnym. Operacyjnie odnosi się to najczęściej do relacji między docelowa stopa zastapienia (i to nie indywidualna, ale systemowa), stopa składki emerytalnej oraz wskaźnikiem obciążenia ludnością starszą. Podejście takie pokazuje jednak raczej zależność stopy zastapienia od stopy składki i struktury demograficznej, przy założonym stałym udziale emerytów w konsumpcji PKB. Jest to, zdaniem M. Góry, ,warunkiem koniecznym ekonomicznej neutralności systemu emerytalnego" ${ }^{49}$. Podkreślić należy jednak, że nawet ścisła indywidualna i globalna matematyczna ekwiwalentność świadczenia nie musi prowadzić do postulowanej stałej proporcji podziału PKB między pokolenie pracujących i emerytów.

W kontekście zabezpieczenia emerytalnego, ze względu na rozłożony w czasie okres nabywania uprawnień emerytalnych oraz ich pobierania, rozważa się solidarność dodatkowo w innym aspekcie. Chodzi mianowicie o metodę finansowania świadczeń: repartycję lub kapitalizację. Podkreśla się

${ }^{45}$ M. Kohli, op. cit., s. 198 i n. M. Kohli wskazuje, że argument odwołujący się do równowagi wkładu i świadczeń w kontekście generacji osób młodych i starszych można podważyć przynajmniej z trzech powodów: 1) dobrobyt osób starszych i młodszych zależy od różnych instytucji, 2) z perspektywy porównawczej wyższe wydatki na osoby młode i starsze nie wykluczają się wzajemnie, 3) istnieją związki wewnątrzgeneracyjne (np. rodzinne), co powoduje, że zasoby płynące do jednej generacji przynosza korzyści także drugiej (op. cit., s. 202).

${ }^{46}$ Szerzej M. Góra, op. cit., s. 64 i n.

${ }^{47}$ Ibidem, s. 107 i n.

48 Ibidem, s. 63.

49 Ibidem, s. 63. 
istnienie solidarności międzypokoleniowej w odniesieniu do świadczeń finansowanych repartycyjnie (bieżące emerytury finansowane sa $\mathrm{z}$ bieżących składek). Należy jednak podkreślić, że także w systemach finansowanych kapitałowo mamy do czynienia z (pośrednią) solidarnością. Polega ona na tym, że następuje ,,przepływ” środków służących bieżącej wypłacie świadczeń od ubezpieczonych do beneficjentów świadczeń za pośrednictwem rynków finansowych. Różnica zatem między repartycją a kapitalizacja ma charakter techniczny. Ubezpieczeni nabywaja instrumenty finansowe, beneficjenci je sprzedaja. W tym sensie (w aspekcie popytu i podaży na instrumenty finansowe) systemy emerytalne finansowane kapitałowo są również wrażliwe na zmiany demograficzne ${ }^{50}$. W momencie jednak wyboru między metodami finansowania lub w ogóle określenia zakresu finansowania kapitałowego należy wziąc pod uwagę aspekt wzrostu PKB generowanego przez wzrost oszczędności ${ }^{51}$, który to może przyczynić się do redukcji składki lub wzrostu przyszłych świadczeń ${ }^{52}$. O solidarności w systemach finansowanych kapitałowo mówi się także w innym aspekcie. Podkreśla się solidarność między grupą, która „,przyczyniła się do powstania kapitału początkowego ${ }^{53}$, a tymi, którzy przystąpili do ubezpieczenia w innym niż początkowy okresie" ${ }^{54}$.

\section{ZMIANY W ZAKRESIE SOLIDARNOŚCI W BAZOWYM ZABEZPIECZENIU EMERYTALNYM W POLSCE PO 1999 R.}

M. Rymsza wskazuje na trzy historyczne konwersje solidarności w ubezpieczeniu społecznym: 1) konwersja od dobrowolnej do przymusowej wzajemności ubezpieczonych, 2) od solidarności poziomej do solidarności pionowej, 3) desolidaryzację programów emerytalnych (związaną z rosnąca rolą nie państwa, jak miało to miejsce wcześniej, ale rynku) ${ }^{55}$. Zdaniem M. Rymszy: ,w ubezpieczeniu emerytalnym nastapiło radykalne ograniczenie wszystkich trzech aspektów solidaryzmu ubezpieczonych: wzajemności ubezpieczeniowej, solidaryzmu obywatelskiego i solidaryzmu międzypokoleniowego, wzrosło natomiast znaczenie przezorności indywidualnej” ${ }^{56}$.

Ograniczenie solidarności poziomej następuje poprzez wprowadzenie indywidualnych kont emerytalnych. Zdaniem M. Rymszy, jest to możliwe w odniesieniu do ubezpieczeń emerytalnych dlatego, że ,starość nie jest typowym ryzykiem socjalnym i program emerytalny można zorganizować przy

\footnotetext{
${ }^{50}$ Szerzej np. N. Barr, The Welfare State as a Piggy-Bank: Information, Risk, Uncertainty, and the Role of the State, Oxford University Press, Oxford, s. 96 i n.

${ }^{51}$ Co nie zawsze ma miejsce (szerzej N. Barr, P. Diamond, op. cit., s. 62 i n.).

52 Trzeba pamiętać, że nie zawsze następuje wzrost oszczędności (szerzej: ibidem, s. 80 i n.).

${ }^{53}$ Pojęcie to rozumiane jest jako wkład w tworzenie aktywów początkowych. Inaczej termin ten jest rozumiany w nowym systemie emerytalnym w Polsce.

${ }^{54}$ B. Rysz-Kowalczyk, op. cit., s. 197; w innym ujęciu N. Barr, Reforming Pensions: Myths, Truths, and Policy Choices, ,International Social Security Review” 55, 2002, s. 15 i n.

${ }_{55}$ M. Rymsza, op. cit., s. 49 i n.

56 Ibidem, s. 54.
} 
założeniu pewności wypłaty świadczenia (a więc przy rezygnacji w okresie akumulacji kapitału z kategorii ryzyka socjalnego)" ${ }^{57}$. Podobne stanowisko reprezentuje M. Góra, twierdząc, że „Obecnie, gdy większość osób rozpoczynających uczestnictwo w systemie emerytalnym przechodzi potem na emeryturę, stosowanie narzędzi ubezpieczeniowych w fazie płacenia składek przestało być celowe. Wciąż ma ono sens w fazie otrzymywanie emerytury, ponieważ długość jednostkowego życia jest nadal zróżnicowana w populacji, a to zróżnicowanie zaczyna się właśnie od poziomu odpowiadającego mniej więcej wiekowi emerytalnemu" ${ }^{58}$. Ze stanowiskiem takim można polemizować, ponieważ zmniejszenie prawdopodobieństwa śmierci w okresie akumulacji uprawnień emerytalnych nie powoduje jego eliminacji ${ }^{59}$. M. Rymsza podkreśla, że chodzi głównie o konta w systemie finansowanym kapitałowo, w którym istnieje możliwość dziedziczenia środków, nie są one jednak własnością ubezpieczonych. Po zmianie podziału składki emerytalnej można także odnieść te rozważania do tak zwanych subkont w I filarze (powstałych wskutek zmniejszenia składki do II filaru na rzecz I filaru od maja 2011 r. $)^{60}$.

Właśnie aspekt dziedziczenia środków w fazie akumulacji kapitału emerytalnego (tj. przed przejściem na emeryturę) decyduje o tym, że nie można mówić o wyrównaniu ryzyka (dożycia wieku emerytalnego) wśród ubezpieczonych. W tym kontekście T. Szumlicz mówi o bezskładkowym ubezpieczeniu na życie wbudowanym w system kapitałowy ${ }^{61}$, a sami Autorzy reformy emerytalnej prezentuja stanowiska krytyczne wobec opcji dziedziczenia ${ }^{62}$. Niekiedy możliwość dziedziczenia kapitału emerytalnego traktuje się jako quasi-rentę wdowią, ale i tutaj można mieć szereg wątpliwości ${ }^{63}$. Poza tym ryzyko śmierci żywiciela jest odrębnym ryzykiem socjalnym, jako że przekazanie połowy środków z konta emerytalnego zmarłego współmałżonka na rzecz drugiego ma charakter obligatoryjny, a druga połowa jest wypłacana wskazanym beneficjentom ${ }^{64}$, a ponieważ istnieje regulacja obligatoryjnego podziału kapitału emerytalnego nabytego w trakcie trwania wspólności majątkowej małżonków, można mówić o istnieniu elementów solidarności pionowej (w ramach lub międzygeneracyjnej, w zależności od wieku beneficjentów i ubezpieczonych). Rozważania powyższe odnoszą się do fazy gromadzenia uprawnień emerytalnych. Nie uregulowano dotąd w pełni zasad wypłat emerytur z drugiego filaru. Biorąc pod uwage obecne lub proponowane rozwiązania (emerytura okresowa i dożywotnia), można powiedzieć, że w fazie wypłaty świadczeń

\footnotetext{
57 Ibidem.

${ }^{58}$ M. Góra, op. cit., s. 50 i 112.

${ }^{59}$ Tym bardziej że śmierć ubezpieczonego jest przesłanką wypłaty renty rodzinnej po zmarłym żywicielu.

${ }^{60}$ Ze względu na to, że konta w I filarze mają charakter raczej administracyjny, tzn. są na nich rejestrowane należne składki emerytalne indywidualnych ubezpieczonych, poza tym nie ma, pomijając wspomniane wyżej subkonta, możliwości dziedziczenia środków.

${ }^{61}$ T. Szumlicz, Ubezpieczenie..., s. 258.

${ }^{62}$ M. Góra, op. cit., s. 120.

${ }^{63}$ J. Ratajczak-Tuchołka, Emerytury kobiet $w$ ubezpieczeniowych systemach emerytalnych $w$ Niemczech i $w$ Polsce, Wydawnictwo Uniwersytetu Ekonomicznego w Poznaniu, Poznań 2010, s. 89.

${ }^{64}$ Istnieje także, o ile tak wskazał ubezpieczony i taka jest wola żyjącego współmałżonka, możliwość przekazania drugiej połowy środków na konto emerytalne tego ostatniego.
} 
w odniesieniu do emerytury okresowej i częściowo emerytury dożywotniej (w tym wypadku przewidywano możliwość wypłaty reszty kapitału w okresie pierwszych trzech lat jej pobierania) można mówić o zachowaniu ograniczaniu solidarności poziomej. Wyrównanie ryzyka ubezpieczeniowego dotyczyć wówczas będzie ryzyka dłuższego (niż to statystycznie przewidziano) życia w fazie pobierania świadczenia emerytalnego.

Ograniczenie solidaryzmu obywatelskiego (solidarność pionowa) ${ }^{65}$ nastapiła głównie poprzez wzmocnienie ekwiwalentności. Tym samym, zdaniem M. Rymszy, zwiększono ryzyko ubóstwa, zwłaszcza dla osób o niestałych biografiach zawodowych. Ze stanowiskiem tym można dyskutować. Wprowadzając formułę ze zdefiniowaną składką (i zdecydowanie ograniczając elementy solidarności pionowej, zwłaszcza wewnątrz grupy ubezpieczonych), przekształcono bowiem jednocześnie niektóre okresy bezskładkowe w składkowe (np. okresy wychowywania dzieci), zmieniając jednocześnie źródło ich finansowania ( $w$ tym wypadku na budżet państwa). Kluczowy w tym momencie dla określenia, czy mamy do czynienia $\mathrm{z}$ solidarnością wewnątrz- czy międzygeneracyjną, jest moment faktycznego opłacenia składki emerytalnej, to jest czy płatność następuje równolegle z wykonywaniem czynności, czy też dopiero w momencie pobierania świadczenia emerytalnego. Jeśli mamy do czynienia z pierwszą sytuacja, to można mówić raczej o solidarności wewnątrzgeneracyjnej. Zmienia się jedynie grupa finansująca świadczenia - zostaje ona poszerzona $z$ grupy ubezpieczonych do płatników podatków (pomija się w tym momencie udział emerytów jako płatników podatków lub przyjmuje się, że ich udział jest znacznie mniejszy niż osób w wieku produkcyjnym).

Druga $\mathrm{z}$ wymienionych wcześniej sytuacji, to jest sytuacja, w której finansowanie elementów wyrównania socjalnego następuje w momencie wypłaty emerytury, ma miejsce na przykład w wypadku świadczenia minimalnego (jako dopłata do sumy emerytur z I i II filaru po spełnieniu określonych warunków). Także tutaj zmieniono źródło jej finansowania $\mathrm{z}$ funduszu ubezpieczonych na budżet państwa, choć także założono obniżenie jej poziomu. W tym aspekcie można raczej mówić o zmianie solidarności pionowej w kierunku od wewnątrzgeneracyjnej do międzygeneracyjnej (o ile przyjmiemy, że dochody podatkowe pochodzą głównie od generacji innej niż generacja pobierająca świadczenia). Natomiast „rozmiar” solidaryzmu (zarówno wewnątrz- jak i międzygeneracyjnego), zarówno przed, jak i po reformie, zależny jest od zakresu (wielkości) redystrybucji, w tym zwłaszcza podstawy wymiaru składki ${ }^{66}$, długości jej opłacania przez podmioty trzecie (i relacji tych wielkości do wysokości uprawnień emerytalnych nabywanych przed $1999 \mathrm{r}$. przy formule emerytalnej ze zdefiniowanym świadczeniem) oraz liczby

\footnotetext{
${ }^{65}$ M. Rymsza, op. cit., s. 48.

${ }^{66}$ Przykładowo podstawa wymiaru składki emerytalnej w trakcie urlopu wychowawczego znacznie różniła się w badanym okresie: w latach 1999-2001 podstawę wymiaru składek na ubezpieczenia emerytalne (i rentowe) stanowiło minimalne wynagrodzenie; od 2002 do maja 2004 r. - kwota zasiłku stałego z pomocy społecznej, od czerwca 2004 do końca 2008 r. - kwota świadczenia pielęgnacyjnego; od 2009-2011 - ponownie kwota minimalnej płacy, od 2012 r. - 60\% przeciętnego wynagrodzenia w poprzednim kwartale, ale nie więcej niż przeciętne indywidualne wynagrodzenie w ostatnich 12 miesiącach przed urlopem wychowawczym.
} 


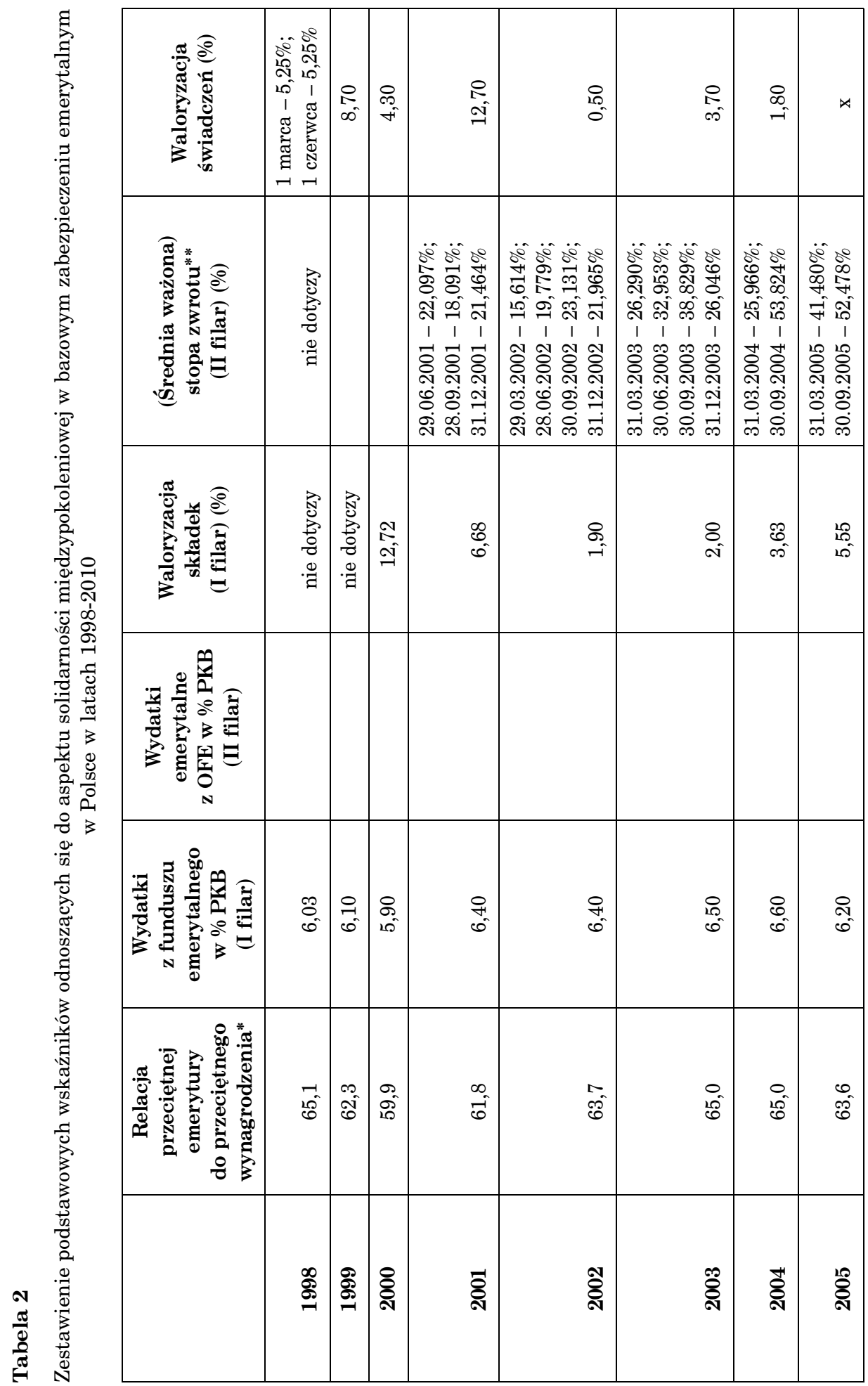




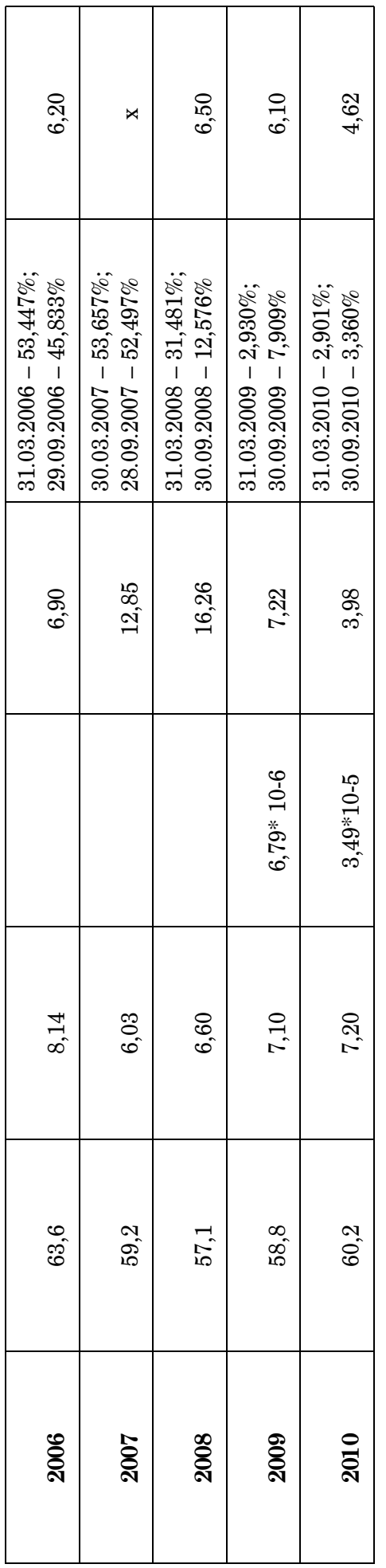

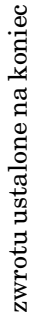

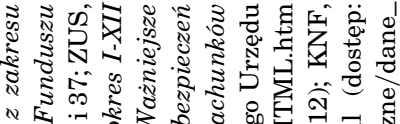

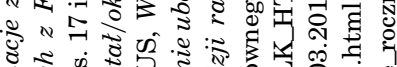

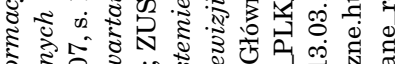

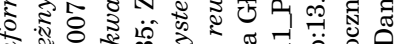

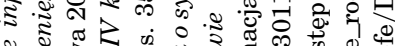
\%

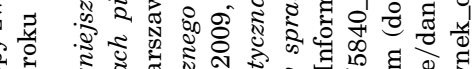

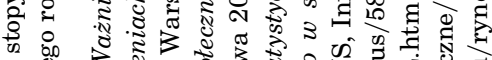

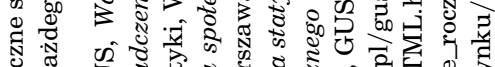
岕 疻

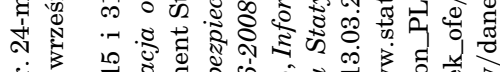
H. คั ฮี हี สี

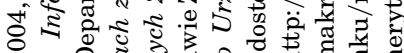
กิ व.7 $\circ \stackrel{\circ}{2}$

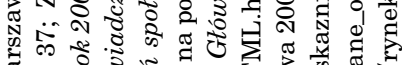

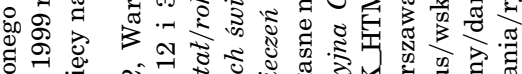
ฮั

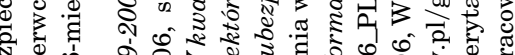
N

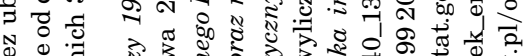

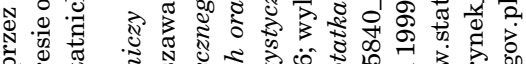

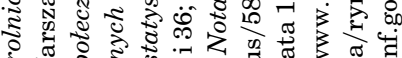

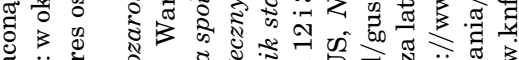
范 $\ddot{\text { कृ }}$

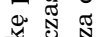

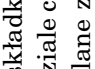

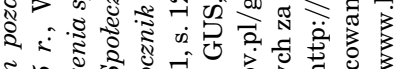

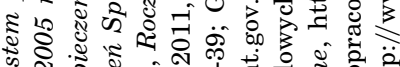
के

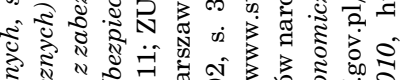

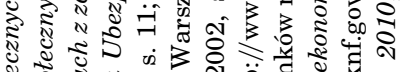

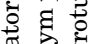

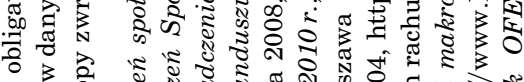
․․

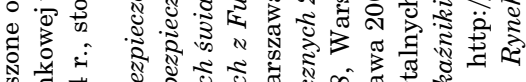
. ब

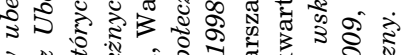
วิ

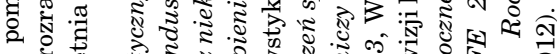

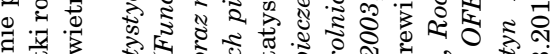

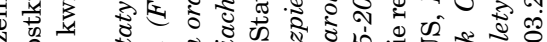

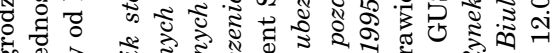
क.

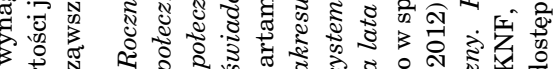
3 范

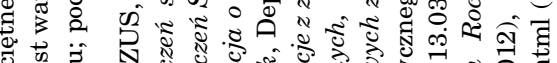

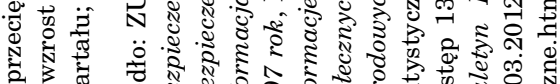
" 
uprawnionych osób. W tym kontekście istotne jest wprowadzenie górnej granicy składkowania. Powoduje ona zmniejszony udział osób relatywnie lepiej sytuowanych (których roczne dochody przekraczają kwotę równą 30-krotnemu przeciętnemu wynagrodzeniu $\mathrm{w}$ gospodarce) $\mathrm{w}$ tworzeniu funduszu ubezpieczeniowego i ograniczeniu solidarności pionowej $\mathrm{w}$ grupie ubezpieczonych. $\mathrm{Z}$ drugiej jednak strony, wprowadzenie formuły ze zdefiniowana składka i zmiana zasad finansowania elementów wyrównania socjalnego głównie w kierunku finansowania $\mathrm{z}$ budżetu państwa powoduje, że wniosek taki może nie być uprawniony, udział osób relatywnie lepiej uposażonych $\mathrm{w}$ dochodach podatkowych państwa jest bowiem znacznie wyższy. Drugim zjawiskiem istotnym reformy $1999 \mathrm{r}$. było wzmocnienie solidarności wewnątrzgeneracyjnej między kobietami a mężczyznami, a konkretnie: solidarności wewnątrz związków, zwłaszcza małżeństw (w kierunku od mężów do kobiet). Jest to efektem zarówno wspomnianej wcześniej instytucji dziedziczenia oraz podziału środków $\mathrm{w}$ razie rozwodu, jak i zastosowania tablic unisex do obliczania wysokości świadczenia.

Analiza zatem rozmiarów i kierunków zmian w odniesieniu do solidarności w zabezpieczeniu emerytalnym, w tym także solidarności międzygeneracyjnej, wymaga uwzględnienia wielu czynników. Biorąc pod uwagę wskaźniki zaproponowane $\mathrm{w}$ punkcie II, dotyczące redystrybucji międzygeneracyjnej, można stwierdzić, że w latach 1998-2010 nastąpił spadek przeciętnej stopy zastąpienia (o około 5 punktów procentowych). Jednocześnie istotnie wzrósł udział świadczeń emerytalnych w PKB (o blisko 1,2 pkt proc.). Udział wydatków związanych z emeryturami okresowymi jest obecnie znikomy (świadczenia wypłacane są dopiero od 2009 r.), ale będzie systematycznie rósł. Przytoczone dane odnośnie do wzrostu relatywnego udziału emerytur w PKB można wyjaśniać między innymi relatywnie większym wzrostem liczby osób pobierających świadczenie w porównaniu z liczbą osób ubezpieczonych (finansujących świadczenia) ${ }^{67}$. Tym samym nawet większy odsetek PKB na świadczenia emerytalne był „,dzielony” między większą liczbę beneficjentów, co skutkowało niższym relatywnym poziomem świadczeń dla tych ostatnich. Udział ów ograniczano, jak wskazuje pobieżna analiza, także poprzez niższą waloryzację świadczeń w stosunku do składek.

W ośmiu badanych okresach (na jedenaście adekwatnych do analizy) sama stopa waloryzacji kapitału w I filarze była wyższa od stopy waloryzacji emerytur, co wskazywałoby na obniżanie relatywnego udziału emerytów w wytwarzanym PKB względem pokolenia finansującego świadczenia emerytalne. W tabeli 2 zaprezentowano stopę zwrotu (średnia ważona dla rynku), która przyjęto jako wskaźnik odzwierciedlający stopę waloryzacji w II filarze. W rzeczywistości jednak bardziej właściwa miara byłaby stopa zysku, która odzwierciedlałaby wzrost wartości kapitału emerytalnego w czasie (uwzględniając ciagły charakter akumulacji i wszystkie koszty). Dane dotyczące stopy zysku nie sa jednak publikowane przez Urząd Komisji Nadzoru Finansowego $(\mathrm{KNF})$, a dostępne szacunki sa przeprowadzane o pewne założenia ${ }^{68}$. I tak,

${ }^{67}$ Odpowiednie publikacje ZUS 2004, 2006, 2011.

${ }^{68}$ Szerzej: MPiPS, op. cit., s. 13 i 14. 
zgodnie z kalkulacja MPiPS stopa zysku w II filarze za okres lipiec $1999 \mathrm{r}$. - kwiecień 2010 r. wynosiła 40,2\%, a wartość środków emerytalnych zaewidencjonowanych na indywidualnym koncie w I filarze o $42,8 \%{ }^{69}$; według innych źródeł rządowych za okres 2000-2010 skumulowana stopa zysku z Otwartych Funduszy Emerytalnych (OFE) kształtowała się na poziomie 60,7\%, a w I filarze skumulowana stopa waloryzacji zaewidencjonowanych środków wyniosła $53,9 \%{ }^{70}$. Te skumulowane wartości (choć byłyby one reprezentatywne dla kohorty/kohort oszczędzających w podanym okresie), uwzględniając proporcje podziału składki emerytalnej, należałoby odnieść do (skumulowanej) stopy waloryzacji świadczeń (w przyszłości także do stopy waloryzacji emerytur kapitałowych). Stąd przytoczone dane dotyczące stóp zwrotu w OFE (średnia ważona, najpierw dwuletnia, potem trzyletnia), stopy waloryzacji z I filaru ${ }^{71}$ oraz stopy waloryzacji świadczeń (z I filaru, a od 2010 r. także emerytur okresowych z II filaru) maja jedynie charakter orientacyjny.

Generalnie zatem analiza danych z tabeli 2 pozwala na wniosek, że udział generacji emerytów (z sytemu powszechnego) w PKB rośnie, ale tempo tego wzrostu jest ograniczane na przykład przez zasady waloryzacji świadczeń emerytalnych (w niektórych okresach rezygnowano nawet $\mathrm{z}$ tej waloryzacji) ${ }^{72}$. Tym samym dąży się raczej nie do utrzymania wartości PKB/emeryta, ale części PKB przeznaczonej w ogóle dla populacji beneficjentów. Nadto, biorąc pod uwagę spadek wskaźnika pokrycia wydatków składkami ${ }^{73}$, można wnioskować,

${ }^{69}$ MPiPS, Informacja Ministra Pracy i Polityki Społecznej dotycząca rozliczenia składek emerytalnych wpłacanych do ZUS i OFE za okres lipiec 1999 r. - kwiecień 2010 r., Warszawa, http://www.mpips.gov.pl/gfx/mpips/userfiles/_public/1_NOWA\%20STRONA/Analizy\%20i\%20raporty /raporty\%20i\%20sprawozdania/polityka\%20spoleczna/skladki\%20emerytalne/1analiza\%20mk\%20maj \%202010\%20popr_25-06-10.pdf (dostęp: 10.09.2011), s. 23.

${ }^{70}$ M. Boni, Autopoprawka do projektu ustawy o zmianie niektórych ustaw zwiazanych z funkcjonowaniem systemu ubezpieczeń społecznych, http://bip.kprm.gov.pl/g2/2011_03/4131_fileot.pdf, s. 2.

${ }^{71}$ Od 2012 r. ma również miejsce waloryzacja składek w I filarze na tzw. subkoncie (konto, na którym ewidencjonuje się środki w wysokości $5 \%$ podstawy wymiaru). Zaznaczyć należy, że wyliczana jest ona inaczej niż stopa waloryzacji fikcyjnego kapitału na indywidualnym koncie w I filarze.

72 Ograniczenie waloryzacji płacowej (przy relatywnie niskiej inflacji i relatywnie większym tempie wzrostu gospodarczego) prowadzi do ograniczania udziału emerytów w zwiększającym się dobrobycie (szerzej na temat waloryzacji w kontekście solidarności międzygeneracyjnej N. Barr, P. Diamond, op. cit., s. 32 i n.). Wprowadzenie od 2012 r. waloryzacji kwotowej uzasadnia się właśnie solidarnością społeczną: „Swiadczenia emerytalno-rentowe są podwyższane w ramach waloryzacji. W bieżącym roku, rząd podjął trudną decyzję, dotyczącą zmiany zasad waloryzacji. Podjęcie tej decyzji było oparte na przyjęciu jako wiodącej - zasady solidarności społecznej. Uznając, że wszyscy powinniśmy ponosić koszty kryzysu gospodarczego, przyjęto jednocześnie, że stosunkowo najmniej tymi kosztami powinni być obciążeni najubożsi świadczeniobiorcy. Waloryzacja kwotowa, polegająca na podwyższeniu wszystkich świadczeń emerytalno-rentowych o jednakową kwotę 71 zł powinna pozwolić zminimalizować negatywne skutki tego kryzysu i pozwolić tym osobom na przejście przez ten ciężki czas 2012 r. stosunkowo bezpiecznie" (MPiPS, http://www.mpips.gov.pl/ubezpieczenia-spoleczne/ubezpieczenie-emerytalne/konsultacje-spoleczne-dotyczace-podniesienia-wieku-emerytalnego/spotkanie-z-parlamentarna-grupa-kobiet-2302-2012 -r/odpowiedz-na-pytanie-nr-4/; dostęp: 13.03.2012).

${ }^{73}$ Wskaźnik ten odnosi się do wszystkich dochodów składkowych i wydatków Funduszu Ubezpieczeń Społecznych; w 2005 r. wynosił 72,8\%, w 2010 r. - zaledwie 55,7\% (ZUS 2011). Pozaskładkowe dochody FUS składają się z dotacji budżetowej (w 2010 r. ok. 63\%) oraz pozostałych dochodów (w 2010 r. ok. 37\%). W pierwszej pozycji zawarte są dotacje z tytułu niedoboru środków wynikających z wprowadzenia górnej granicy oskładkowania, druga pokrywa przede wszystkim niedobory wynikające z przekazania części składki do OFE (do maja 2011 r. było to 7,3\% podstawy wymiaru z łącznej składki 19,52\% podstawy wymiaru). 
że zwiększył się udział redystrybucji (wymuszonej solidarności), głównie międzygeneracyjnej, i to wykraczającej w odniesieniu do generacji finansującej świadczenia poza grono ubezpieczonych (o ile przyjmiemy, że podatki ludności w wieku produkcyjnym stanowią główne źródło dochodów podatkowych).

\section{KONKLUZJE}

Analiza zmian w bazowym zabezpieczeniu emerytalnym w Polsce wskazuje na ograniczenie solidarności poziomej (międzygeneracyjnej), co wynika z wprowadzenia dziedziczenia kapitału emerytalnego w II filarze oraz rozszerzenie owego dziedziczenia na subkonta w I filarze (od maja 2012 r.).

Równocześnie można zaobserwować ograniczenie solidarności pionowej wewnątrzgeneracyjnej (na skutek redukcji elementów wyrównania socjalnego) i zmianę jej kierunku (z grupy ubezpieczonych na wszystkich podatników). Towarzyszy temu jednak, dzięki rozwiązaniom instytucjonalnym, wzmocnienie solidarności wewnątrzgeneracyjnej między małżonkami/partnerami, także w wyniku eliminacji czy osłabienia innych elementów solidarnościowych.

Zmiana formuły emerytalnej $\mathrm{z}$ formuły ze zdefiniowanym świadczeniem na formułę ze zdefiniowaną składką, ale także zmiany w zakresie waloryzacji świadczeń ograniczyły zakres solidarności międzygeneracyjnej ${ }^{74}$, zastępując ją częśsiowo solidarnością wewnątrzgeneracyjną (ze względu na bieżące finansowanie elementów wyrównania socjalnego). Jednocześnie wzmocnienie ekwiwalentności w systemie było opcja reform, która miała największe polityczne szanse realizacji, w przeciwieństwie do zmiany warunków dostępu do świadczeń czy wieku emerytalnego ${ }^{75}$. Należy pamiętać, że cel stabilności finansowej systemu, a nie realizacja celu związanego z określonym ,,poziomem” sprawiedliwości międzygeneracyjnej czy wewnątrzgeneracyjnej były przyczyną reform.

Podkreślić należy, że (sama) zmiana metody finansowania nie prowadzi do zmiany zakresu solidarności międzygeneracyjnej, podobnie zresztą jak prywatyzacja systemu rozumiana jako wprowadzenie podmiotów prywatnych do realizacji zabezpieczenia społecznego. Nie ma bowiem prostego podziału na solidarnościowy system administrowany przez podmioty publiczne i obowiązkowy ekwiwalentny (świadczeniowo) system zarządzany przez podmioty prywatne - chodzi raczej pewną równowagę w zakresie realizowania obu tych wartości w całości systemu obligatoryjnego ${ }^{76}$.

Nie należy zapominać, że bazowy system emerytalny jest jedynie częścią zabezpieczenia emerytalnego, a ten jedynie subsystemem zabezpieczenia na starość. Rozważając solidarność międzypokoleniową, należy brać pod uwagę także inne obszary, zwłaszcza opiekę zdrowotna, system edukacji i świadczeń

${ }^{74}$ Ta tendencja jest zresztą typowa dla Europy, zob. M. Kohli, op. cit., s. 201.

75 C. Arza, op. cit., s. 121.

${ }^{76}$ M. Rein, K. Anderson, The Interdependence of the System of Solidarity and the System of Equivalence, w: C. Arza, M. Kohli (red.), op. cit., s. 134. 
rodzinnych. Z punktu widzenia zmiany dystrybucji dóbr istotne jest uwzględnienie (rosnącej) siły wyborczej osób starszych. Istotne, by pamiętać, że równość lub nierówność w podziale zasobów publicznych między różne grupy wiekowe jest kwestią normatywną i może być postrzegana w kategoriach niesprawiedliwości lub nieefektywności, zasadniczo jednak taki stan znajduje swoje uzasadnienie w tym, że grupy te są zmienne (i to zarówno, jeśli chodzi o dookreślenie ich granic wiekowych, jaki i ze względu na cykl życia człowieka) ${ }^{77}$.

dr Joanna Ratajczak-Tuchotka

Uniwersytet Ekonomiczny w Poznaniu

j.ratajczak@ue.poznan.pl

\section{SOLIDARITY AND PENSION REFORM IN POLAND IN 1999-2011}

\section{Summary}

Solidarity, and especially intergenerational solidarity (and intergenerational 'conflict'), is often discussed within the context of the pension reform. However, the predominant point of view in these discussions is only financial sustainability of the pension system and the influence of pension reform on the reduction of public spending. Other issues, like the consequences of the reform on the (re)distribution of welfare, are usually disregarded.

This paper analyses pension reforms in Poland in 1999-2011 from the point of view of the changes (vertical and horizontal) in solidarity between generations. The main conclusion is that both the horizontal and vertical solidarity have been weakened. Furthermore, the vertical solidarity has been converted: there is less intergenerational solidarity in favour of intragenerational solidarity.

${ }^{77}$ M. Kohli, op. cit., s. 197; szerzej s. 204 i n. 
